\title{
ANALISIS PROKSIMAT DAN NILAI KALOR PADA PELLET BIOSOLID YANG DIKOMBINASIKAN DENGAN BIOMASSA LIMBAH BAMBU
}

\author{
I Nyoman Sukarta ${ }^{1}$ dan Putu Sri Ayuni ${ }^{2}$ \\ 1,2Jurusan Analis Kimia FMIPA Universitas Pendidikan Ganesha \\ e-mail: nyoman.sukarta@undiksha.ac.id
}

\begin{abstract}
Abstrak
Dalam penelitian ini biosolid dan biomassa limbah bambu dimanfaatkan sebagai bahan bakar dengan cara mengubahnya menjadi pellet bahan bakar. Tujuan pembuatan pellet bahan bakar dengan berbagai komposisi untuk mengetahui perbandingan jenis pellet biosolid dan limbah bambu ditinjau dari pengujian proksimat. Manfaat pembuatan pellet biosolid dapat mengurangi penimbunan sampah yang menyebabkan pencemaran lingkungan. Hasil penelitian menunjukkan Nilai kadar air tertinggi terdapat pada pellet dengan komposisi limbah bambu dan biosolid (90:10) yaitu sebesar 7,55\%, nilai kadar abu tertinggi terdapat pada pellet limbah bambu dan biosolid dengan komposisi (50:50) yaitu sebesar 49,33\%, nilai zat volatile tertinggi terdapat pada pellet limbah bambu dan biosolid dengan komposisi (90:10) yaitu sebesar 68,70\%, nilai karbon padat tertinggi terdapat pada pellet limbah bambu dan biosolid dengan komposisi (90:10) yaitu sebesar 11,99\%. Sementara itu, nilai kalor tertinggi terdapat pada pellet dengan komposisi limbah bambu dan biosolid (90:10) yaitu sebesar 3,692 kal/g.
\end{abstract}

Kata kunci: biosolid, limbah bambu, pellet, proksimat, nilai kalor

\begin{abstract}
In this study, biosolid and biomass bamboo waste used as fuel by turning them into fuel pellets. The purpose of making fuel pellets with different compositions to compare the type of biosolid pellets and bamboo waste in terms of proximate testing. Benefits manufacture biosolid pellets can reduce the accumulation of waste that cause environmental pollution. The results showed the highest water content value contained in the pellets with bamboo and biosolid waste kompesisi (90:10) that is equal to $7,55 \%$, the highest value of ash content contained in bamboo waste and biosolid pellets with the composition (50:50) that is equal to $49,33 \%$, the highest value of volatile substances contained in waste bamboo and biosolid pellets with the composition (90:10) that is equal to $68,70 \%$, the highest value of solid carbon contained in the waste bamboo and biosolid pellets with the composition (90:10) that is equal to $11,99 \%$. Meanwhile, the highest calorific value contained in the pellets with bamboo and biosolid waste composition (90:10) in the amount of 3,692 $\mathrm{cal} / \mathrm{g}$.
\end{abstract}

Keywords: biosolid, pellets, bamboo waste, proximate, calorific value

\section{PENDAHULUAN}

Pellet bahan bakar adalah bahan padat yang dihaluskan dan dimampatkan sehingga memungkinkan konsistensi dan efesiensi pembakarannya menjadi lebih baik dari keadaan aslinya. Pellet umumnya dibuat dari limbah kayu dan atau limbah pertanian umumnya memiliki nilai kalor yang tinggi dengan kandungan mineral yang rendah.
Dalam hal ini pemanfaatan biosolid sebagai pellet bahan bakar yang dikombinasikan dengan limbah biomassa bambu akan dapat mengkompensasi kekurangan potensi energi dari biosolid melalui bentuk pellet.

Biosolid adalah sludge (lumpur) yang telah diolah. Sludge adalah produk samping dari hasil pengolahan air 
limbah. Sludge umumnya mengandung 28,75 $\%$ padatan (Roy et al., 2011). Oleh karena itu, sludge limbah domestik merupakan suatu padatan, semi padatan, atau residu cair yang berasal dari pengolahan limbah domestik. Adapun lumpur limbah perkotaan adalah padatan yang dihasilkan dari proses pengolahan air limbah yang masih memerlukan penanganan lebih lanjut. Dalam hal ini, biosolid adalah sludge yang telah distabilisasi melalui suatu proses yang bertujuan untuk mengurangi potensi pathogeniknya. Dalam proses pengolahan air limbah, sludge dapat dihasilkan baik pada tahap pengolahan primer, skunder, maupun tersier. Dengan demikian, sludge dapat dihasilkan baik melalui proses pengolahan secara fisik, kimia, maupun biologi pada tahapan pengolahan air atau air limbah. Namun demikian, sludge yang dipertimbangkan sebagai biosolid adalah sludge yang telah diolah dan dihasilkan dari proses pengolahan yang memanfaatkan mikroorganisme aerobik maupun anaerobik.

Biosolid terutama dihasilkan dari pengolahan air limbah perkotaan. Adapun air limbah perkotaan terutama berasal dari air yang digunakan dalam aktivitas rumah tangga Beberapa industri kecil juga membuang limbahnya melalui saluran sistem pengolahan limbah perkotaan. Selain yang berasal langsung dari aktivitas rumah tangga, air limbah yang dihasilkan dari timbuan sampah perkotaan (lindi) juga dipertimbangkan sebagai air limbah perkotaan. Berdasarkan sumbernya tersebut, komposisi biosolid terdiri dari campuran dari bahan organik (volatile matter), bahan anorganik (inert material), dan air. Bahan-bahan organik volatil berasal dari hasil penguraian bahan-bahan organik rantai panjang seperti karbohidrat, lemak, protein yang terdapat dalam air limbah. Selain itu bahan organik tersebut juga bersal dari mikroorganisme yang telah mati. Adapun bahan-bahan anorganik pada biosolid umumnya berupa logam-logam mineral maupun logam berat serta tanah dan pasir yang terikut dalam aliran limbah. Kualitas akhir dari biosolid yang dihasilkan tergantung pada kualitas air limbah yang masuk ke sistem pengolahan dan proses pengolahannya.

Saat ini, biosolid umumnya ditangani dengan cara: mengaplikannya pada suatu lahan, ditimbun (landfilling), dikomposkan, diuraikan secara anaerobik, dan diinsinerasi. Di Indonesia, sebagian besar dimanfaatkan dengan cara diaplikasikan ke suatu lahan atau sebagai tanah urug. Padahal, bila dilihat dari potensi komponen utama penyusunnya yakni berupa bahan-bahan organik terutama bahan-bahan organik mudah menguap (volatile organic matter), biosolid dapat dimanfaatkan sebagai salah satu sumber energi alternatif. Keberadaan biosolid akan terus meningkat sejalan dengan pertumbuhan penduduk dan ekonomi yang terjadi saat ini di negara-negara sedang berkembang termasuk Indonesia. Di sisi lain kebutuhan akan sumber daya energi akan terus meningkat sedangkan ketersediaanya semakin terbatas terutama yang bersumber dari bahan bakar fosil. Oleh karena itu, pemanfaatan biosolid untuk energi menjadi upaya yang sangat penting.

Penelitian yang berkaitan dengan pemanfaatan berbagai limbah biomassa untuk pellet bahan bakar telah banyak dilakukai seperti: Nielson et al., (2009) limbah kayu sebagai pellet dan Lehtikangas (2001) menggunakan serbuk gergaji. Namun demikian belum banyak dilakukan penelitian dengan memanfaatkan biosolid sebagai pellet bahan bakar atau bahan bakar turunan sludge "sludge derived fuel" (SDF) dalam bentuk pellet.

Penelitian ini bertujuan untuk mengembangkan pellet bahan bakar kombinasi biosolid dengan limbah bambu dan menilai kelayakan teknis pemanfaatan biosolid sebagai substitusi parsial dari pellet kayu. Analisis proksimat dilakukan pada pellet yang dihasilkan untuk mengetahui potensi pemanfaatan pellet ini sebagai bahan bakar alternatif.

\section{METODE}

Penelitian ini bertujuan untuk menyelidiki hubungan antara penambahan biosolid dalam pembuatan pellet dari biomassa dengan kualitas pellet. Adapun rancangan dari penelitian ini dapat dilihat pada Gambar 1. Bahan- 
bahan yang digunakan untuk pembuatan pellet biosolid adalah: (1) Biosolid lumpur; (2) Limbah bambu; (3) Perekat kanji; (4) Air sebagai campuran bahan perekat.

Adapun alat yang digunakan dalam penelitian ini adalah: (1) Blender listrik; (2)
Mesh atau penyaring; (3) Cetakan pellet; (4) Baskom kecil; (5) Timbangan digital; (6) Bomb calorimeter; (7) High temperature furnace; (8) Kaca arloji.

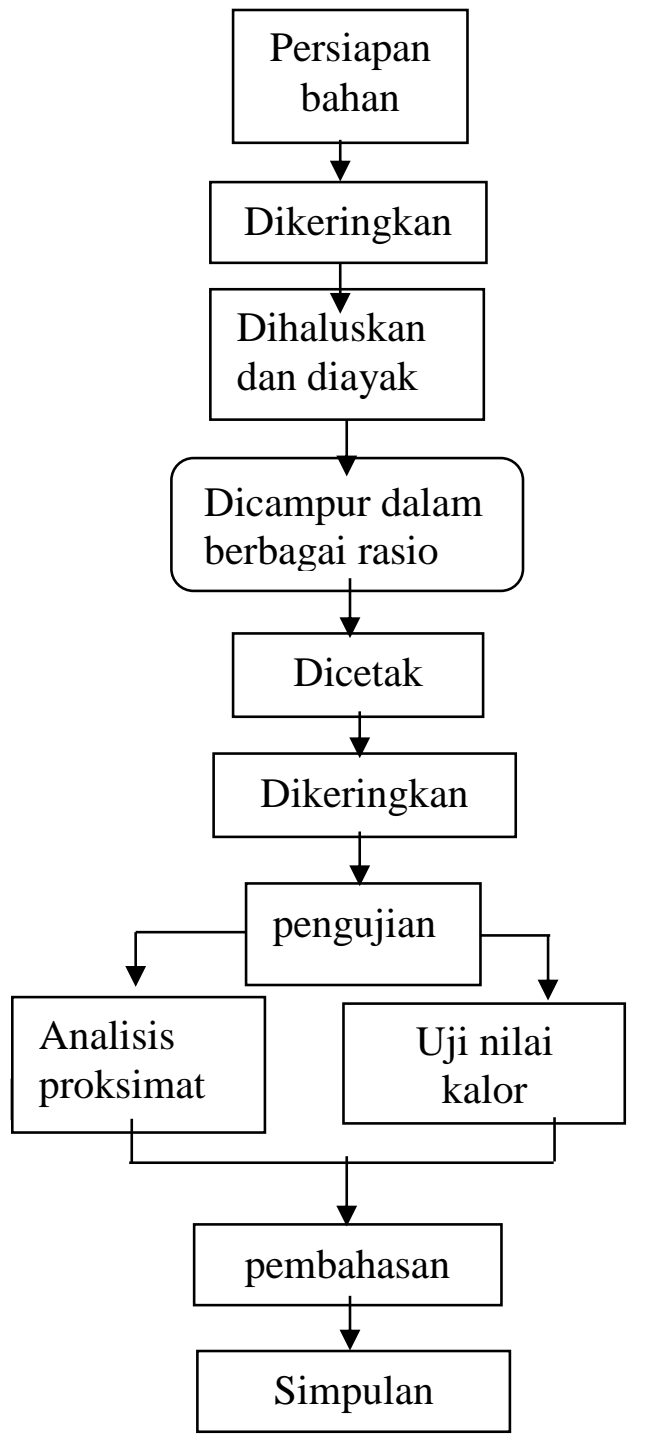

Gambar 1. Diagram alir penelitian

Pengujian yang dilakukan dalam penelitian ini adalah:

\section{Pengujian Proksimat}

Pengujian proksimat merupakan pengujian yang meliputi pengujian kadar air (Mouisture content), kadar abu (Ash Content), bahan yang mudah menguap (Volatile Matter). Pengujian proksimat ini dengan cara pemanansan atau pembakaran pellet biosolid ke dalam high temperature furnece.
Kadar air (Mouisture content)

Perhitungan persentase kadar air (Mouisture content) yang terkandung di dalam pellet tersebut menggunakan standar ASTM D-3173-03 dengan persamaan sebagai berikut:

Mouisture content $\%=\frac{a-b}{a} \times 100 \%$...(1) Dengan,
$\mathrm{A}=$ Massa awal pellet biosolid (gram)
$\mathrm{b}=$ Massa pellet biosolid setelah pemanansan $107^{\circ} \mathrm{C}$ (gram) 


\section{Kadar Abu (ash content)}

Perhitungan persentase kadar abu (ash content) pellet biosolid menggunakan standar ASTM D-3174-04 dengan persamaan sebagai berikut:

Ash content, $\%=\frac{d}{a} \times 100 \%$

Dengan,

$\mathrm{d}=$ Massa pellet setelah pemanasan 750 ${ }^{\circ} \mathrm{C}$ (gram)

\section{Zat yang mudah menguap (Volatile Matter).}

Perhitungan persentase kadar zat yang mudah menguap (volatile matter) yang terkandung di dalam pellet biosolid menggunakan standar ASTM D-3175-02 dengan persamaan sebagai berikut:

$$
\text { Volatile matter, } \%=\frac{b-c}{a} \times 100 \% \ldots .
$$

Dengan,

$$
\begin{aligned}
\mathrm{C}= & \text { Massa pellet biosolid setelah } \\
& \text { pemanasan pada temperatur } 950 \\
& { }^{\circ} \mathrm{C}(\mathrm{gram})
\end{aligned}
$$

\section{Pengujian nilai kalor} Nilai kalor (heating value) suatu
bahan bakar diperoleh dengan
menggunakan bomb calorimeter. Nilai kalor yang diperoleh melalui bomb calorimeter adalah nilai kalor atas atau highest heating value (HHV) dan nilai kalor bawah atau lowest heating value (LHV). Perhitungan nilai kalor kotor berdasarkan standar ASTM D240.

Dengan menggunakan bomb calorimeter dapat dihitung panas yang diserap air dalam bomb calorimeter dan energi setara bomb calorimeter setara HHV dan LHV. Panas yang diserap air dalam bomb calorimeter dihitung dengan menggunakan rumus:

$$
\mathrm{Q}=\mathrm{m} . \mathrm{Cp} . \Delta \mathrm{T} \text {. }
$$

Dengan,

$\mathrm{Q}$ : Panas yang diserap $(\mathrm{kJ})$ $\mathrm{m}$ : Massa air di dalam bomb calorimeter (gram)

$\mathrm{Cp}$ : Specific heat $4,186 \mathrm{~kJ} / \mathrm{kg}^{\circ} \mathrm{C}$

$\Delta \mathrm{T}$ : perbedaan temperatur $\left({ }^{\circ} \mathrm{C}\right)$

LHV dan HHV dihitung dengan persamaan berikut:

$$
\mathrm{LHV}=\frac{(m \times C p \times \Delta T)}{m_{\text {pellet }}}
$$

Untuk menghitung HHV digunakan persamaan:

$\mathrm{HHV}=(\mathrm{T} 2-\mathrm{T} 1-\mathrm{Tkp}) \times(\mathrm{Cv}(\mathrm{kJ} / \mathrm{kg})$

$\mathrm{LHV}=\mathrm{HHV}-3240 \mathrm{~kJ} / \mathrm{kg}$

Maka, HHV = LHV + 3240 kJ/kg... (6)

Dengan,

$\mathrm{T} 1$ = temperatur air pendingin bomb calorimeter sebelum pembakaran $\left({ }^{\circ} \mathrm{C}\right)$

$\mathrm{T} 2$ = temperatur air pendingin bomb calorimeter sesudah pembakaran $\left({ }^{\circ} \mathrm{C}\right)$

Tkp = kenaikan temperatur disebabkan kawat pembakaran

$\mathrm{HHV}=$ highest heating value $(\mathrm{kJ} / \mathrm{kg})$

$\mathrm{LHV}=$ lowest heating value $(\mathrm{kJ} / \mathrm{kg})$

\section{HASIL DAN PEMBAHASAN}

Analisis Proksimat dan Nilai Kalor

Sebelum dilakukan pencampuran limbah bambu dan biosolid maka dilakukan penentuan karakteristik masing-masing bahan yang akan digunakan untuk membuat biopellet seperti disajikan pada tabel 1.

Tabel 1 Data karakteristik pellet

\begin{tabular}{ccc}
\hline Parameter & \multicolumn{2}{c}{ Bahan Baku } \\
& Limbah Bambu & Biosolid \\
\hline (Mouisture In Air Dried Sample) & 7,91 & 1,94 \\
(\%) & 2,40 & 88,96 \\
(Ash Content) (\%) & 75,15 & 8,47 \\
(Volatile Matter) (\%) & 14,54 & 0,63 \\
(Fixed carbon) (\%) & 4,105 & $*$ \\
(Calorific Value) (cal/g) & &
\end{tabular}

Dari tabel 1 di atas dapat dibuat grafik karakteristik bahan baku pellet sebagai pada gambar 1 . 


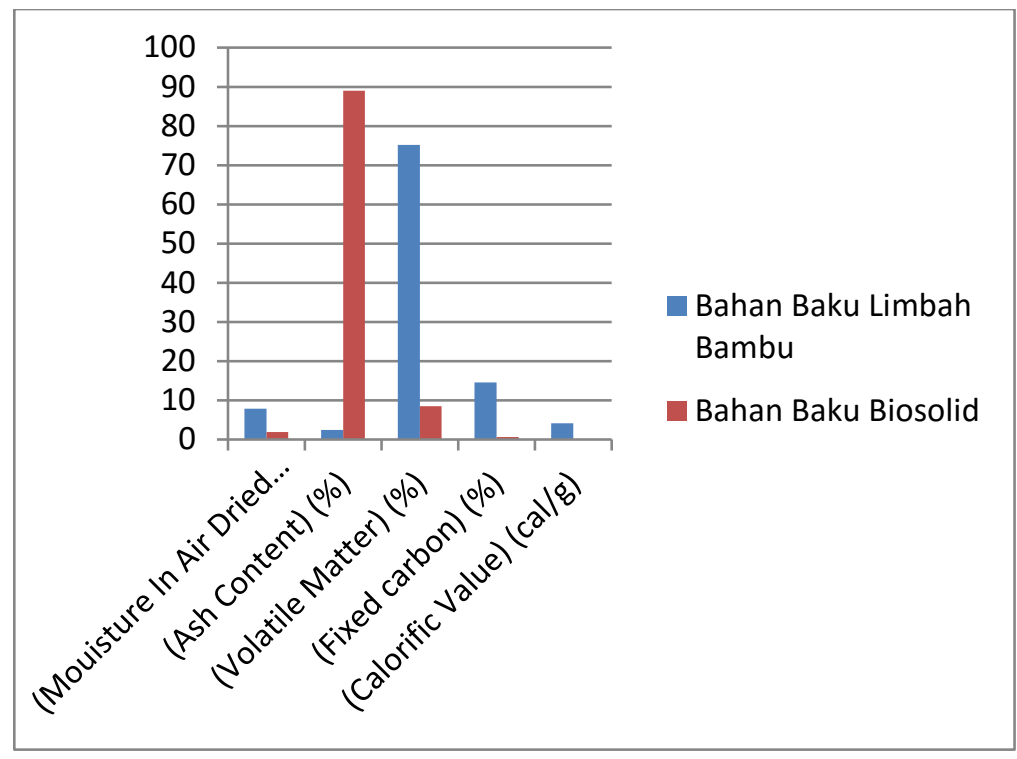

Gambar 1. Karakteristik bahan baku pellet

Dari gambar 1 di atas terlihat bahwa semua parameter kecuali kadar abu (ash content) yang dimiliki oleh bahan baku limbah bambu lebih tinggi kandungannya dibandingkan dengan bahan baku biosolid.

Untuk mengetahui perbedaan kualitas pellet yang dihasilkan dengan penambahan biosolid maka dilakukan pencampuran biomassa yaitu limbah kayu dengan biosolid masing-masing dengan lima komposisi. Sebagaimana halnya dengan bahan baku maka, kualitas pellet dengan lima komposisi tersebut juga dikarakterisasi berdasarkan nilai kandungan air (Mouisture In Air Dried Sample), kadar abu (Ash Content), bahan mudah terbang (Volatile Matter), karbon padat (Fixed carbon), dan nilai kalornya (Calorific Value). Data analisa proksimat pellet biomassa limbah bambu dan biosolid yang dihasilkan dari masingmasing komposisi disajikan pada tabel 2 berikut:

Tabel 2 data analisis proksimat pellet biomasa pada berbagai komposisi

\begin{tabular}{ccccccc} 
No & Komposisi & $\begin{array}{c}\text { (Moisture } \\
\text { in air dried } \\
\text { sample }) \\
\%\end{array}$ & $\begin{array}{c}\text { (Ash) } \\
\%\end{array}$ & $\begin{array}{c}\text { Volatile } \\
\text { Matter } \\
\%\end{array}$ & $\begin{array}{c}\text { Fixed } \\
\text { Carbon } \\
\%\end{array}$ & $\begin{array}{c}\text { Calorific } \\
\text { Value } \\
(\text { Cal/g) }\end{array}$ \\
\hline 1 & Pellet1 (90:10) & 7,55 & 11,76 & 68,70 & 11,99 & 3,692 \\
2 & Pellet2 (80:20) & 7,46 & 19,63 & 62,33 & 10,58 & 3,300 \\
3 & Pellet3 (70:30) & 7,39 & 31,98 & 51,91 & 8,72 & 2,711 \\
4 & Pellet4 (60:40) & 6,28 & 34,17 & 50,91 & 8,64 & 2,639 \\
5 & Pellet5 (50:50) & 5,14 & 49,33 & 39,88 & 5,65 & 1,966 \\
\hline
\end{tabular}

Dari tabel 1 di atas dapat dibuat grafik karakteristik pellet limbah bambu dan biosolid pada berbagai komposisi seperti disajikan pada gambar 2 . 


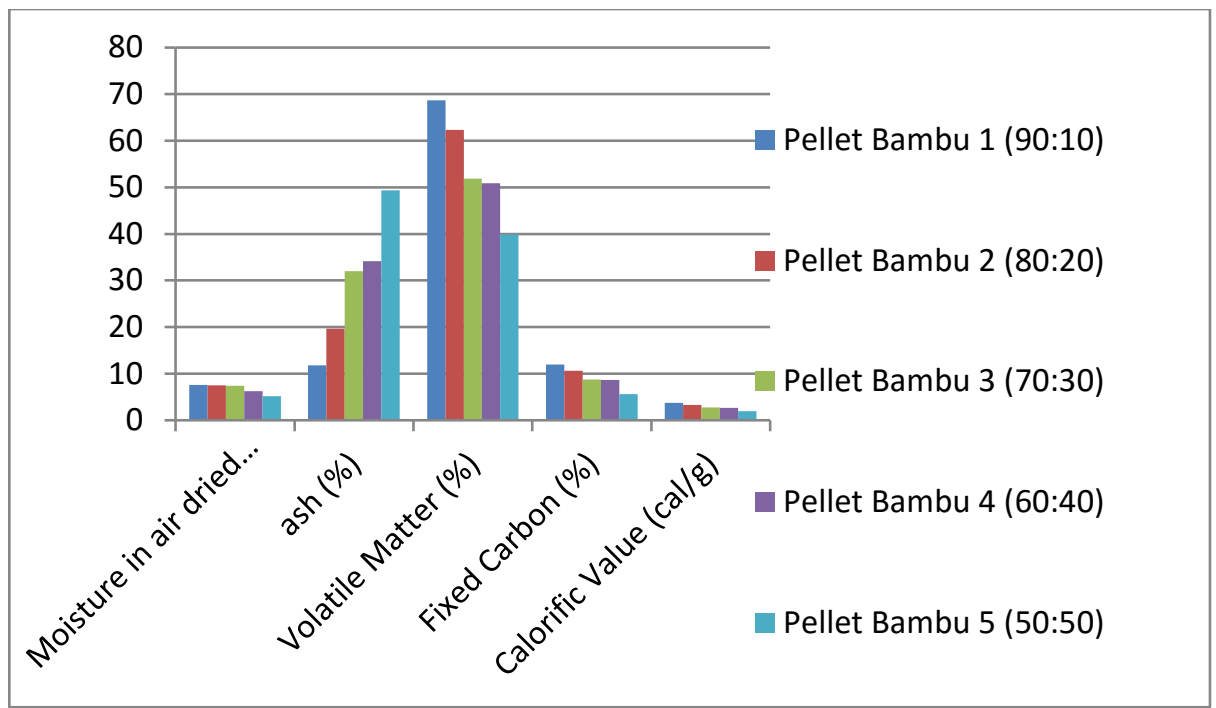

Gambar 2. Karakteristik pellet limbah bambu dan biosolid pada berbagai komposisi

Dari tabel perhutungan analisa proksimat limbah bambu dan biosolid di atas, kandungan air (Mouisture In Air Dried Sample) teringgi terdapat pada pellet dengan komposisi limbah bambu dan biosolid (90:10) yaitu sebesar 7,55\% sedangkan kandungan air (Mouisture In Air Dried Sample) terendah terdapat pada pellet dengan komposisi limbah bambu dan biosolid (50:50) yaitu sebesar 5,14\%.

Menurut Lehtikangas (2001) kadar air rata-rata produk pellet komersial adalah 10$12 \%$. Rendahnya kadar air yang diperoleh dalam penelitian ini disebabkan oleh lamanya pengeringan yang dilakukan. Sebagaimana halnya briket, pellet juga dibuat melelui proses pemadatan. Tekanan pemadatan yang tinggi juga dapat mempengaruhi kadar air pada pellet. Tekanan pemadatan yang tinggi dapat saling mengisi pori-pori bahan sehingga dapat mengurangi kadar air dalam pori tersebut. (Sriharti \& Salim, 2011). Dalam hal ini proses pemadatan merupakan proses dewatering. Dalam penelitian ini pemadatan dilakukan dengan dongkrak hidrolik kapasitas 3 ton.

Kadar air menentukan kualitas pellet sebagai bahan bakar. Menurut Obernberger, et al., (2004), Kadar air yang tinggi menurunkan nilai kalor sehingga akan mengurangi efisiensi konversi dan kinerja karena sejumlah energi akan digunakan untuk menguapkan air tersebut. Selain itu, juga akan mencegah pembakaran lebih lanjut. Begitu juga sebaliknya. Kadar air yang rendah akan meningkatkan efisiensi dan kinerja dan melancarkan keberlancutan pembakaran. Kadar air adalah sifat yang sangat penting dan sangat mempengaruhi karakteristik pembakaran pellet. Kadar air juga mempengaruhi perubahan suhu internal dalam bahan bakar karena penguapan endotermik maupun karena total energi yang dibutuhkan untuk membawa hingga mencapai suhu pembakaran. Selama pembakaran, kadar air dalam pellet (bahan bakar) akan menyerap panas atau kalor untuk proses penguapan sehingga akan mengurangi nilai kalor dari pellet secara signifikan. Hal ini akan menyebabkan terjadinya kehilangan kalor atau panas untuk mendorong reaksi pembakaran sehingga suhu pembakaran menjadi lebih rendah. Akibatnya akan terjadi pembakaran yang tidak sempurna terhadap bahanbahan yang sifatnya volatil dan akan terjadi deposisi karbon yang tidak terbakar (asap) di cerobong asap atau pada bagian bawah alat memasak seperti panci yang relatif sulit untuk dibersihkan. Adanya asap yang signifikan akan dapat menghalangi aliran gas buangan dan mengurangi transfer kalor/panas ke alat memasak. Di samping itu, kadar air yang tinggi juga menyebabkan kesulitan dalam pengapian.

\section{Kandungan Abu (Ash)}

Residu yang tersisa setelah pembakaran bahan bakar disebut dengan abu (ash). Semakin tinggi kandungan abu 
pada bahan bakar maka nilai kalor dari bahan bakar tersebut juga semakin rendah. Begitu juga sebaliknya semakin rendah kandungan abu pada bahan bakar maka nilai kalor bahan bakar tersebut juga akan semakin tinggi. Abu terbentuk dari bahanbahan mineral yang terikat dalam struktur karbon biomassa selama pembakarannya. Di samping itu, abu juga merupakan pengotor-pengotor dari bahan bakar. Kandungan abu dari bahan bakar ditentukan dengan memanaskan bahan bakar tersebut pada temperatur $450-500^{\circ} \mathrm{C}$ selama kurang lebih 1 (satu jam). Abu adalah bahan yang tidak mudah terbakar. Menurut Obernberger, at al., (2004) kadar abu yang tinggi akan menghasilkan polusi yang parah.

Kadar abu (ash) tertinggi terdapat pada pellet dengan komposisi limbah bambu dan biosolid (50:50) yaitu sebesar $49,33 \%$ sedangkan terendah pada komposisi (90:10) yaitu sebesar 11,76\%. $\mathrm{Hal}$ ini menunjukkan bahwa semakin banyak komposisi lumpur pada pellet biosolid maka kadar abunya juga semakin tinggi pula. Hal ini terjadi karena pada lumpur lebih banyak mengandung zat-zat yang sulit dibakar dan sulit diuapkan seperti mineral yang terikat dalam struktur karbon pada lumpur sehingga residu pembakaran lebih banyak akibatnya abu yang terbentuk juga semakin banyak.

\section{Volatile Matter}

Bahan-bahan yang mudah menguap (volatile matters) adalah zat-zat yang ditemukan didalam bahan bakar seperti methana, hidrokarbon, hidrogen, karbonmonoksida, nitrogen dan gas-gas yang tidak terbakar. Bahan volatile (VM) ditentukan dengan memasukkan bahan bakar dalam furnace pada temperatur $900 \pm 15^{\circ} \mathrm{C}$ selama 15 menit. Bahan-bahan yang akan menguap ketika pellet dikeringkan pada temperatur terkendali disebut kandungan bahan-bahan volatile dalam pellet. Bahan-bahan volatile tersebut menentukan kemampuan pembakaran dari suatu bahan bakar. Bahan bakar dengan kandungan volatile matters tinggi berarti sebagian besar nilai kalor yang dimiliki akan dilepaskan sebagai uap pembakaran (Obernberger, at al., 2004).
Kadar zat mudah terbang (volatile matter) tertinggi terdapat pada pellet limbah kayu dan biosolid dengan komposisi (90:10) yaitu sebesar $74,05 \%$ sedangkan kadar zat volatile matter terendah terdapat pellet dengan komposisi limbah kayu dan biosolid (50:50) yaitu sebesar $52,50 \%$.

\section{Karbon Padat (Fixed Carbon)}

Kandungan karbon (kandungan karbon ultimat) dari suatu bahan bakar bertanggung jawab pada kandungan energi bahan bakar. Kandungan karbon padat (Fixed Carbon) bahan bakar tidak sama dengan karbon ultimat. Karbon padat (Fixed Carbon) adalah karbon yang tersisa setelah bahan-bahan mudah menguap (volatile matter) dilepaskan dari proses pembakaran. Berbeda dengan karbon ulimat yang hilang bersama hidrokarbon karena volatilitasnya. Oleh sebab itu, karbon ultimat akan menentukan jumlah karbondioksida yang dihasilkan selama pembakaran oleh suatu bahan bakar. Fixed Carbon (FC) digunakan sebagai estimasi jumlah arang yang akan dihasilkan dari sampel bahan bahar. Oleh sebab itu Fixed Carbon ditentukan dengan mengurangkan massa volatile matter (VC), kadar air dan kadar abu dari massa awal suatu sampel bahan bakar atau sering dikenal dengan istilah by difference.

Kadar karbon (fixed carbon) tertinggi terdapat pada pellet limbah bambu dan biosolid dengan komposisi (90:10) yaitu sebesar $11,99 \%$ sedangkan kadar karbon terendah terdapat pada pellet limbah bambu dan biosolid dengan komposisi (50:50) yaitu sebesar 5,65\%.

\section{Nilai Kalor (Colorific Value)}

Nilai kalor (Calorific Value) tertinggi pada penelitian ini terdapat pada pellet limbah kayu dan biosolid dengan komposisi (90:10) yaitu sebesar 3,692 Cal/g. sedangkan nilai kalor terendah terdapat pada pellet dengan komposisi limbah kayu dan biosolid dengan komposisi (50:50) yaitu sebesar 1,966 Cal/g. Nilai kalor adalah ukuran kandungan energi standar dari bahan bakar. Nilai kalor didefinisikan sebagai jumlah panas yang dihasilkan bila suatu massa bahan bakar terbakar secara sempurna dan produk pembakarannya 
didinginkan sampai 298 K. Nilai kalor disebut sebagai nilai kalor bruto (GCV) atau nilai kalor lebih tinggi (HHV) ketika panas laten kondensasi uap air diperhitungkan dalam nilai kalor ini. Namun, dalam pembakaran kadar air yang terkandung dalam bahan bakar dan terbentuk dalam proses pembakaran terbawa sebagai uap air sehingga panas tidak tersedia. Hal ini sangat berguna, karena untuk mengurangkan panas kondensasi air tersebut dari nilai kalor bruto. Hasilnya dikenal sebagai nilai kalor bersih (NCV) atau nilai kalor yang lebih rendah. Dalam bomb calorimeter uap air terkondensasikan, maka nilai kalor yang dihasilkan dengan menggunakan alat tersebut adalah kalor bruto.

\section{PENUTUP}

Dari hasil penelitian dan pembahasan dapat disimpulkan bahwa nilai kadar air tertinggi terdapat pada pellet dengan komposisi limbah bambu dan biosolid (90:10) yaitu sebesar $7,55 \%$, nilai kadar abu tertinggi terdapat pada pellet limbah bambu dan biosolid dengan komposisi (50:50) yaitu sebesar 49,33\%, nilai zat volatile tertinggi terdapat pada pellet limbah bambu dan biosolid dengan komposisi (90:10) yaitu sebesar $68,70 \%$, nilai karbon padat tertinggi terdapat pada pellet limbah bambu dan biosolid dengan komposisi $(90: 10)$ yaitu sebesar $11,99 \%$. Sementara itu, nilai kalor tertinggi terdapat pada pellet dengan komposisi limbah bambu dan biosolid (90:10) yaitu sebesar 3,692 kal/g.

\section{DAFTAR PUSTAKA}

Lehtikangas, p. 2001. Quality properties of pelletised sawdust, logging residues and bark. Biomass and Bioenergy 20 (2001) 351-360

Nielsen, N.P.K., Gardner, D.J., Poulsen, T. \& Felby, C. (2009). Importance of temperature, moisture content and species for the conversion process of wood residues into fuel pellets. Wood and Fiber Science, 41(4), 414-425.

Obernberger, L and Thek, G. 2004. Physical Characterisation and Chemical Composition of densified Biomass Fuels with Regard to Their
Combustion Behavior, Biomass and Bioenergy, 27, 653-669.

Roy, M.M., Dutta, A., Corscadden, K., Havard, P., and Dickie, L. 2011. Review of biosolids management options and co-incineration of a biosolid-derived fuel. Waste Management 31, 2228-2235

Sriharti Dan Salim, T. 2011. Pengaruh Komposisi Bahan Terhadap Karakterisasi Pellet Limbah Biji Jarak Pagar (Jatropha Curcas Linn). Teknologi Indonesia. Vol 34, 40-48. 